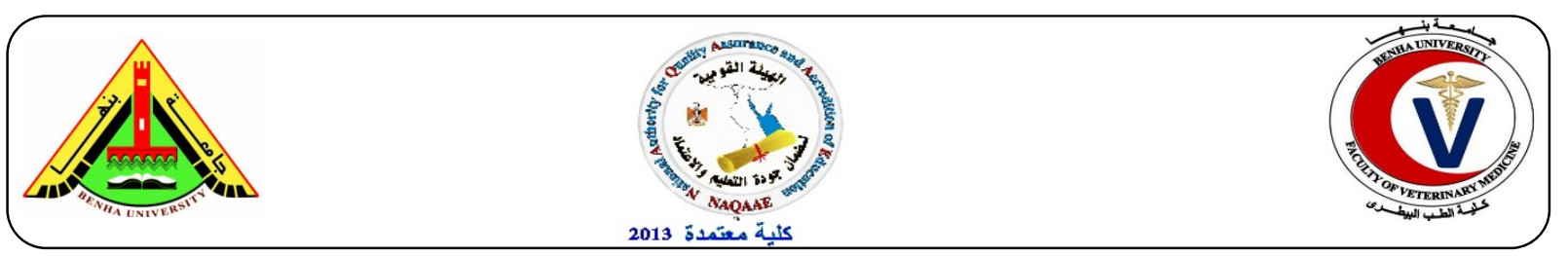

\title{
Baby Grivet Monkey Kidney (BGM) a new cell line for adaptation of fowl pox virus
}

\author{
El-Bagoury, G.F. ${ }^{1}$; El-Nahas, E.M. ${ }^{1}$; Olfat A. Nakhla ${ }^{2}$ and Nesma M. Hassan ${ }^{2}$ \\ ${ }^{1}$ Department of virology, Faculty of Veterinary Medicine, Benha University, Egypt. ${ }^{2}$ Veterinary Serum and Vaccine \\ Research Institute, Abbassia, Cairo
}

\begin{abstract}
A B S T R A C T
The need to economic, sensitive and easily maintained cell cultures use for massive production of fowl pox vaccine was necessary. We adapted Fowl pox virus (FPV) Baudette strain on Primary chicken embryo fibroblast (CEF), Baby Grivet Monkey Kidney cell line (BGM) and African green monkey kidney (Vero) cell lines. The highest virus titers were $10^{6.5}$ after the $9^{\text {th }}$ passage in CEF and $10^{6.2}$ after the $12^{\text {th }}$ passage on BGM while Vero cells were abortive to the virus. BGM cells were selected for study cytopathic effect (CPE) and growth kinetic as it easily maintained than primary CEF cells. The characteristic CPE were rounding till $6^{\text {th }}$ passage with intracytoplasmic inclusion by the $7^{\text {th }}$ passage and syncytium formation appeared from the $9^{\text {th }}$ passage till the $13^{\text {th }}$ passage. The virus was highly cell associated for the first $84 \mathrm{~h}$ post inoculation(PI) with a titer of $10^{4.5}$ then a maximum titer was $10^{6.2}$ in cell free portion after $120 \mathrm{~h}$ PI. In conclusion, BGM were considered a new susceptible cell for growth of FPV with best harvesting time 120h PI to obtain a maximum titer for subsequent vaccine production.
\end{abstract}

Key words: Fowl pox virus, CEF, BGM, Vero cell.

(http://www.bvmj.bu.edu.eg)

(BVMJ-31(1): 136-139, 2016)

\section{INTRODUCTION}

Fowl pox virus (FPV) was classified as members of the genus Avipox virus which belongs to the family Poxviridae (MacLachlan and Dubovi, 2011). This dermotropic virus was present in two forms in chicken. The cutaneous form (dry form) of the disease is characterized by the appearance of nodular lesions on the comb, wattles, eyelids, and other non feathered areas of the body. Cutaneous eye lesions will interfere with the bird's ability to reach food and water. In the diphtheritic form (wet pox), diphtheritic yellowish lesions occur on the mucous membranes of the mouth, esophagus, and upper parts of the trachea (Tripathy and Reed 2008). Control against virus infection is realized by vaccination using attenuated vaccine either propagated on specific pathogen free embryonated chicken egg (SPF-ECE) or tissue culture (Dasgupta et al., 2007). In Egypt, Namaa (1998) prepared fowl pox virus vaccine from whole CAM of the infected ECE, while Soad (1986) prepared FPV vaccine on chicken embryo rough cells (CER) as a tissue culture adapted fowl pox vaccine.

Because, SPF-ECE are expensive, hardly handled during work. The need to economic, sensitive and easily maintained cell cultures use for massive production of fowl pox vaccine was necessary (Dasgupta et al., 2007).so the present study compared between CEF as primary cell culture and BGM and Vero cells as established cell line for adaptation of fowl pox virus Beaudette strain for further use in massive vaccine production.

\section{MATERIALS AND METHODS}

\subsection{Virus strains}

Fowl pox virus vaccinal strain (Baudette strain) was kindly supplied from Pox Vaccine production and Research Department, Veterinary Serum and Vaccine Research Institute (VSVRI), Abbasia, Egypt. The strain was refreshed on the chorioallantoic membranes (CAM) of SPF-ECE yield a titer of $10^{6.7} \mathrm{EID}_{50} / \mathrm{ml}$. it was used in the propagation on CEF, BGM and Vero cells.

\subsection{Cell cultures}

Primary chicken embryo fibroblast (CEF) cells were prepared from SPF-ECE as described by Villegas, (1990). Baby Grivet Monkey Kidney cell 
line (BGM) is a continuous cell line, which was obtained kindly from VACSERA, Agouza, Giza. These cells were propagated according to Joshi and Namital (2011). African green monkey kidney (Vero) was kindly supplied by Pox Dept, VSVRI, and were propagated and maintained according to Soad (1986). These cells were used in adaptation and titration of FPV.

\subsection{Propagation and titration of fowl pox virus on CEF, BGM and Vero cells Virus}

Briefly the virus was propagated in different cell culture by removal of growth medium from confluent sheets of cell cultures. The virus was inoculated and left for an hour at $37^{\circ} \mathrm{C}$ for adsorption. Maintenance medium was added, then incubated at $37^{\circ} \mathrm{C}$ and examined daily microscopically for the appearance of cytopathic changes. The inoculated cultures were exposed to three cycles of freezing and thawing and centrifuged at 3000 r.p.m. for 10 minutes. The supernatant fluid was used for inoculation of the next passages. Serial tenfold dilution from each passage were prepared and titration process was performed on CEF (Villegas, 1990), BGM (Joshi and Namital2011) and Vero (Soad 1986). The titer was calculated according to Reed and Muench (1938).

\subsection{Growth kinetics of fowl pox on BGM cell line}

It was done according to Fernandes et al. (1981), BGM monolayers were inoculated with 0.2 $\mathrm{ml}$ virus suspension per tube from passage $13^{\text {th }}$ of FPV on BGM cells with a titer of $10^{6.2} \mathrm{TCID}_{50} / \mathrm{ml}$. Virus adsorption was allowed for 1 hour at $37^{\circ} \mathrm{C}$ followed by addition of $2 \mathrm{ml}$ of maintenance medium per tube and incubation was done at $37^{\circ} \mathrm{C}$ for several days. Four tubes were collected at different intervals $(2,6,12,24,36,48,60,72,84$, $96,108,120,132$ and 144 hours post inoculation) for assessment of virus infectivity of each cell free and cell associated cultured viruses. The infected culture medium represented the cell free virus. The infected cells harvested by washing their cultures with maintenance media and subjected to three cycles of freezing and thawing represented the cell associated virus.

\section{RESULTS}

\subsection{Titration of FPV on CEF, BGM and Vero cells}

It was observed that, highest virus titers were $10^{6.5}$ after the 9th passage in CEF and 106.2 after the 12th passage on BGM while Vero cells were $10^{2.1}$ by the $7^{\text {th }}$ passage (table 1). This indicates the higher susceptibility of both CEF and BGM for FPV.

\subsection{Growth characters of FPV on BGM cells}

It was shown that, FPV produce few cell rounding by the first 3 passages, then become prominent and distributed till the $7^{\text {th }}$ passage with intracytoplasmic inclusion with the onset of CPE $6^{\text {th }}$ day for the first 2 successive passages then become 4 days till the $9^{\text {th }}$ passage and harvestation day was the $7^{\text {th }}$ day PI till the $9^{\text {th }}$ passage. Thereafter, cell syncytia were dominant from the $9^{\text {th }}$ till $13^{\text {th }}$ passage of the virus with the onset of CPE at $3^{\text {rd }}$ day PI and the harvestation day was the $5^{\text {th }}$ day PI (table 2$)$.

\subsection{Growth kinetics of FPV on BGM cells}

The virus were highly cell associated for the first $84 \mathrm{~h}$ post inoculation(PI) with a titer of $10^{4.5}$ then a maximum titer were $10^{6.2}$ in cell free portion after 120h PI (table 3 and figure 1).

Table1. titration of different passages of FPV on CEF, BGM and Vero cell lines

\begin{tabular}{lccc}
\hline Passage & \multicolumn{3}{c}{ Titer $\left(\log _{10}\right.$ TCID $\left.50 / \mathrm{ml}\right)$} \\
\cline { 2 - 4 } & CEF & BGM & Vero \\
\hline 1 & 4.5 & N.D & N.D \\
2 & 4.5 & N.D & N.D \\
3 & 4.7 & 3.7 & 1.2 \\
4 & 5.0 & N.D & 2.0 \\
5 & 5.2 & N.D & 2.0 \\
6 & 5.5 & 4.2 & 2.0 \\
7 & 5.7 & N.D & $* 2.1$ \\
8 & 6.0 & 5.0 & 2.0 \\
9 & 6.5 & 5.5 & N.D \\
10 & 6.5 & 5.7 & N.D \\
11 & N.D & 6.0 & N.D \\
12 & N.D & $* 6.2$ & N.D \\
13 & N.D & $* 6.2$ & N.D \\
\hline
\end{tabular}

* The highest titer ND: not done

\section{DISCUSSION}

The fowl pox virus was adapted and titrated on CEF, BGM and Vero cells. In CEF, gradual increase in the titer had occurred and reached $10^{5.7}$ $\mathrm{TCID}_{50} / \mathrm{ml}$ by the $7^{\text {th }}$ passage, and reached the highest titer of the virus $10^{6.5} \mathrm{TCID}_{50} / \mathrm{ml}$ by the $9^{\text {th }}$ passage and persisted stable in the $10^{\text {th }}$ passage. These findings were correspondent to that of Koehler and Schwoebel (1956), Namaa (1998) and Omar et al., (2014), who studied the propagation of fowl pox virus in chicken embryo fibroblast cell cultures and found that there was coincidence 
Table 2. CPE Characters of FPV on BGM cell line

\begin{tabular}{lccc}
\hline \multirow{2}{*}{$\begin{array}{l}\text { Passage } \\
\text { no. }\end{array}$} & \multicolumn{2}{c}{ Cytopathic effect } & \multirow{2}{*}{ Form of CPE } \\
\cline { 2 - 3 } & onset & Harvest & \\
\hline 1 & $6^{*}$ & 7 & Few cell \\
2 & 6 & 7 & rounding \\
3 & 5 & 7 & \\
4 & 4 & 7 & Rounding of \\
5 & 4 & 7 & most cells \\
6 & 4 & 7 & Intracytoplasmic \\
7 & 3 & 6 & inclusions \\
8 & 3 & 6 & Syncetial \\
9 & 3 & 5 & formation (giant \\
10 & 3 & 5 & cells) and cell \\
11 & 3 & 5 & necrosis \\
12 & 3 & 5 & \\
13 & 3 & 5 & \\
*day post-inoculation & &
\end{tabular}

Table3. Growth kinetics of fowl pox on BGM cell line

\begin{tabular}{lcc}
\hline \multirow{2}{*}{$\begin{array}{l}\text { Time post } \\
\text { inoculation } \\
\text { per hours }\end{array}$} & \multicolumn{2}{c}{$\begin{array}{c}\text { Virus titre expressed in } \log _{10} \\
\text { TCID }\end{array}$ 促l } \\
\cline { 2 - 3 } & CFV & CAV \\
\hline 2 & 1.6 & 1.7 \\
6 & 1.6 & 2.0 \\
12 & 2.0 & 2.6 \\
24 & 2.0 & 2.8 \\
36 & 1.9 & 3.6 \\
48 & 1.7 & 3.8 \\
60 & 1.7 & 4.0 \\
72 & 2.0 & 4.6 \\
84 & 3.5 & 4.5 \\
96 & 5.0 & 4.0 \\
108 & 5.9 & 3.7 \\
120 & 6.2 & 3.6 \\
132 & 6.2 & 3.4 \\
144 & 6.1 & 3.0 \\
\hline
\end{tabular}

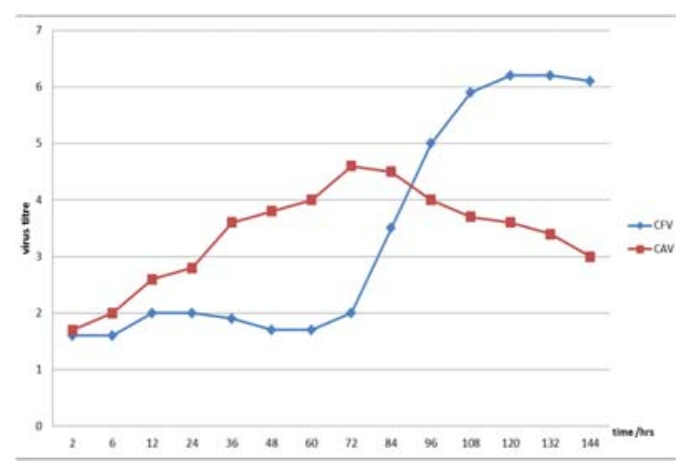

Figure (1): Growth curve of tissue culture adapted fowl pox virus on BGM cell line between the increase in virus titer and the cytopathic effect and the titers were relatively similar to those in infected chicken embryos.

Although CEF cells seemed sensitive and showed rapid and complete $\mathrm{CPE}$, these cells were difficult to be maintained as a monolayer, to be economic to use for massive production of fowl pox vaccine. Therefore, the use of more stable cell lines like BGM and Vero cells were necessary for economic FP vaccine preparation. Therefore, the highest titer recorded on CEF $10^{6.5} \mathrm{TCID}_{50} / \mathrm{ml}$ was chosen to be transferred and propagated on cell lines as BGM and Vero Weli et al., (2005) and Joshi and Namital (2011).

The adapted fowl pox virus on CEF cells was transmitted to grow on BGM cell line. The full adaptation of the virus to these cells were observed after 8 serial passages with characteristic cellular changes appeared as rounding, clumping of cell, intracytoplasmic inclusion bodies, vacuolation and degeneration with gradual increase in titer $10^{6.2}$ $\mathrm{TCID}_{50} / \mathrm{ml}$ by the $12^{\text {th }}$ and $13^{\text {th }}$ passages. This progress in the infectivity titre was as previously reported by Joshi and Namital (2011) and agreed with Sainova et al., (2005), Weli et al., (2005) who succeeded to propagate APV in mammalian cell cultures and challenge the hypothesis that APV cannot undergo a full replication cycle in mammalian cells.

The highest titer in Vero cell was $10^{2.1}$ $\mathrm{TCID}_{50} / \mathrm{ml}$. This results indicated that Vero cell line was not suitable for propagation of FPV, the same results were observed by Soad (1986), who reported that Vero cell line wasn't suitable for the growth of fowl pox virus (Vero is abortive for FPV).

The behavior of Baudette strain of fowl pox strain after being adapted on the BGM cell line was studied. The logarithmic increase in virus titers started from 48 hours post inoculation (PI) with maximum titer at 120 hours PI. Then a clear decrease occurred from 120 to 144 hours post inoculation which indicated that the best time for vaccine harvestaion was the $5^{\text {th }}$ day post inoculation. These results agree with El-Dahaby et al., (1971), Michael (1981), Soad (1986) and Namaa (1998), who found that the highest titers of FPV propagated in CEF cell culture were gradually increased until the 5th day post inoculation when it reached its maximum growth. On the other hand, Gafford et al., (1969) and Rai and Sethi (1972), reported that peak titer of FPV in CEF reached 72 hours PI. 
The logarithmic difference between the titer of the cell free virus (CFV) and cell-associated (CAV) is quite high (about $2.6 \log _{10}$ ) but it is preferable to include both cell-associated and cell-free virus in the harvested material for vaccine preparation to increase the final titer of the virus used in vaccine preparation. These findings were in agree with Maiti et al., (1991) who reported that the extra and intracellular viruses have difference in their antigenicity which help in development of immune-genicity. Also, Fernands et al., (1981) reported that extracellular virus of FPV was more immunogenic than intracellular virus which is due to presence of excess antigenic protein.

\section{REFERENCES}

Dasgupta, A., Hammarlund, E., Slifka, M.K., Früh, K. 2007. Cowpox Virus Evades CTL Recognition and Inhibits the Intracellular Transport of MHC Class I Molecules. J. Immun. 178, 1654-16.

El-Dahaby, H., Sokker, I.M.H., El-Sabbagh, A.H., Nassar, M.I. 1971. Behaviour of an Egyptian fowl pox virus strain in tissue culture. J. Vet. Sci., UAR, 8:107.

Fernandes, G., Sharma, S.N., Tanwani, S.K. 1981. Studies on tissue culture adapted fowl pox disease vaccine with particular reference to immunogenicity of intracellular and extracellular virus. Ind. Vet. J. 58, 599 -604.

Gafford, L.G.; Sinclair, F., Randal, C.C. 1969. Growth cycle of fowl pox virus and change in plaque morphology and cytopathology by contaminating mycoplasma. Virol. 37, 464467.

Joshi, R. K, Namital, J. 2011. Growth and cytopathogenecity of afield isolate of fowl pox virus in BGM-70 cell line. Ind. J. Comp. Microb., Immun. Infec. Dis., 32, 19-21.

Koehler, H., Schwoebel, W. 1956. Propagation of fowl pox virus in tissue culture. Zbl. Bakt. I. Orig, 166: 454.

MacLachlan, N. J., Dubovi, E.J (2011). Poxviridae. In MacLachlan, N.J. and Dubovi, E.J. editors, Fenner's veterinary virology. 4th ed. London; Boston: Academic press, pp,157-160.
Maiti, N.K., Oberoi, M.S., Sharma, S.N. 1991. Comparative studies on the antigenicity of extra and intracellular viruses of fowl pox. Comp Immune Microbiol. Infect. Dis., 14, $59-62$.

Michael, A.1. 1981. Further studies on fowl pox vaccines and their efficacy in vaccinating birds. Ph.D. thesis (Poultry Diseases) Cairo University.

Namaa, A. Mohammed. 1998. Study on trial for preparation of fowl pox vaccine locally on embryonated specific pathogen free eggs. M.V.Sc. thesis, Faculty of Veterinary Medicine, Cairo University.

Omar, A.B., Amira, A. El-Said, Amal, A. Fatouh, Bassiouny, A. I., Nermeen M. Elsayed (2014): Trials for increasing the infectivity titer of fowl pox vaccines prepared on SPF embryonated chicken egg and tissue culture. SCVMJ, 35, 212-222.

Rai, A., Sethi, M.S. 1972. Adaptation and growth cycle of fowl pox virus in fibroblast cultures of chick embryo. Ind. J. Anime Sci., 42: 137.

Reed, L. J., Muench, H. 1938. A simple method of estimating fifty percent end points. Am. J. Hyg., $27: 493-497$.

Sainova, I.V., Kril, A.I., Simeonov, K.B., Popova, T.P., Ivanov I.G. 2005. Investigation of the morphology of cell clones, derived from the mammalian EBTr cell line and their susceptibility to vaccine avian poxvirus strains FK and Dessau. J. Virol. Meth, 124, 37-40.

Soad, M. Soliman. 1986. Immunological and virological studies on fowl pox vaccine. Ph.D. Thesis, Faculty of Veterinary Medicine, Cairo University.

Tripathy, D.N., Reed, W. M. 2008. Avian pox in: Diseases of Poultry, 12th Ed. Clanek, B.W. Barnes, H.J. Beard, C.W.; Reid, W.M., Yoder, Jr. H.W. eds. Iowa State University Press., Iowa, USA, pp,291-307.

Villages, P. 1990. Laboratory Manual, Avian Disease. The University, College of Veterinary Medicine, Athens, Georgia, USA.

Weli SC., Nilssen O., Traavik, T. 2005. Avipox virus multiplication in a mammalian cell line. Virus Res, 109, 39-49. 